\title{
Nutrient-cycling microbes in coastal Douglas-fir forests: regional-scale correlation between communities, in situ climate, and other factors
}

\author{
Philip-Edouard Shay ${ }^{1 *}$, Richard S. Winder ${ }^{2}$ and J. A. Trofymow ${ }^{1,2}$ \\ ${ }^{1}$ Centre for Forest Biology, Department of Biology, University of Victoria, Victoria, BC, Canada, ${ }^{2}$ Canadian Forest Service, \\ Pacific Forestry Centre, Natural Resources Canada, Victoria, BC, Canada
}

OPEN ACCESS

Edited by:

Tim Daniell,

The James Hutton Institute, UK

Reviewed by:

Gwen-Aelle Grelet,

Landcare Research - Manaaki

Whenua, New Zealand

Petra Fransson,

Swedish University of Agricultural

Sciences, Sweden

*Correspondence:

Philip-Edouard Shay,

Centre for Forest Biology, Department

of Biology, University of Victoria,

P.O. Box 3020 STN CSC, Victoria,

BC V8W 3N5, Canada peshay@uvic.ca

Specialty section:

This article was submitted to

Terrestrial Microbiology,

a section of the journal

Frontiers in Microbiology

Received: 05 June 2015 Accepted: 22 September 2015

Published: 08 October 2015

Citation:

Shay P-E, Winder RS

and Trofymow JA (2015)

Nutrient-cycling microbes in coastal

Douglas-fir forests: regional-scale correlation between communities, in

situ climate, and other factors.

Front. Microbiol. 6:1097.

doi: 10.3389/fmicb.2015.01097
Microbes such as fungi and bacteria play fundamental roles in litter-decay and nutrientcycling; however, their communities may respond differently than plants to climate change. The structure (diversity, richness, and evenness) and composition of microbial communities in climate transects of mature Douglas-fir stands of coastal British Columbia rainshadow forests was analyzed, in order to assess in situ variability due to different temperature and moisture regimes. We compared denaturing gradient gel electrophoresis profiles of fungi (18S-FF390/FR1), nitrogen-fixing bacteria ( $\mathrm{NifH}$ universal) and ammonia-oxidizing bacteria (AmoA) polymerase chain reaction amplicons in forest floor and mineral soil samples from three transects located at different latitudes, each transect spanning the Coastal Western Hemlock and Douglas-fir biogeoclimatic zones. Composition of microbial communities in both soil layers was related to degree days above $0^{\circ} \mathrm{C}(2725-3489)$, while $\mathrm{pH}(3.8-5.5)$ best explained shifts in community structure. At this spatial scale, climatic conditions were likely to directly or indirectly select for different microbial species while local site heterogeneity influenced community structure. Significant changes in microbial community composition and structure were related to differences as small as $2.47 \%$ and $2.55^{\circ} \mathrm{C}$ in mean annual moisture and temperature variables, respectively. The climatic variables best describing microbial composition changed from one functional group to the next; in general they did not alter community structure. Spatial distance, especially associated with latitude, was also important in accounting for community variability (4-23\%); but to a lesser extent than the combined influence of climate and soil characteristics (14-25\%). Results suggest that in situ climate can independently account for some patterns of microbial biogeography in coastal Douglas-fir forests. The distribution of up to $43 \%$ of nutrientcycling microorganisms detected in forest soils responded to smaller abiotic gradients than host trees.

Keywords: DGGE, nitrogen-fixation, temperature, moisture, nitrogen, fungi, carbon, ammonia-oxidizing bacteria

Abbreviations: $\mathrm{BEC}$, biogeoclimatic ecosystem classification; \%C, carbon mass fraction $\%$ in fine soil; $\mathrm{C}$, central; $\mathrm{C} / \mathrm{N}$, mass fraction ratio of carbon to nitrogen in fine soil; $\mathrm{Co} / \mathrm{F}$, ratio of coarse to fine fraction mass; $\mathrm{DD}$, degree days above $0^{\circ} \mathrm{C} ; \mathrm{DF}$, coastal Douglas-fir; MS, mean annual soil moisture; $\mathrm{MS}_{\min }$, mean annual extreme minimum soil moisture; $\mathrm{MS}_{\max }$, mean annual extreme maximum soil moisture; \% , nitrogen mass fraction \% in fine soil; $\mathrm{n}$, nothern; PCNM, principal coordinates of neighbor matrices; PET, potential evapo-transpiration; s, southern; $\mathrm{TA}$, mean annual air temperature; $\mathrm{TA}_{\min }$, mean annual extreme minimum air temperature; $\mathrm{TA}_{\max }$, mean annual extreme maximum air temperature; $\mathrm{TR}$, transition between coastal Western Hemlock and coastal Douglas-fir BEC zones; TS, mean annual soil temperature; $\mathrm{TS}_{\min }$, mean annual extreme minimum soil temperature; $\mathrm{TS}_{\max }$, mean annual extreme maximum soil temperature; $\mathrm{WH}$, coastal Western Hemlock. 


\section{Introduction}

Ecological niches are multidimensional; trees therefore have adapted to both above- and below-ground environmental factors, whether abiotic or biotic. There is growing evidence of the close links and specificity between above and below-ground communities (e.g., Wardle et al., 2004; van der Heijden et al., 2008), likely as a result of a complex system where both vegetation and microbes evolve and drive the structure of each other's communities. However, positive and negative effects are not necessarily correlated above- and below-ground, although both contribute in an additive way to overall fitness (Morrien et al., 2011). Microbial communities provide key ecological functions, are usually well-adapted to a tree species genotype (e.g., Finzi et al., 1998; Ste-Marie and Houle, 2006), but can respond differently than above-ground flora to abiotic stressors (e.g., Nantel and Neumann, 1992; Kranabetter et al., 2009) and potentially to climate change. Previous regional-scale studies of the influence of climate on microbial biogeography in forest soils have been confounded by spatial or plant-related effects (Staddon et al., 1998; Bahram et al., 2012).

Co-adapted soil communities are important because longterm forest growth and resilience depends on below-ground processes such as appropriate organic matter degradation and nutrient cycling (van der Heijden et al., 2008). Microbiota are for the most part responsible for the decay of organic matter and recycling of nutrients from plant inaccessible forms (i.e., $\mathrm{N}_{2}$ gas, complex organic polymers) to plant accessible ones (i.e., $\mathrm{NH}_{4}{ }^{+}$, $\mathrm{NO}_{3}{ }^{-}, \mathrm{PO}_{4}{ }^{+}$and organic monomers; Prescott et al., 1993; Elsas et al., 2007; Finlay, 2007; Prosser, 2007). In this study we used polymerase chain reaction (PCR) and denaturing gradient gel electrophoresis (DGGE) as an inexpensive, replicable technique to efficiently screen the principal constituents of nutrient-cycling microbial communities (Nicolaisen and Ramsing, 2002; Vainio et al., 2005; Fierer and Jackson, 2006; Oros-Sichler et al., 2007; Hoshino and Morimoto, 2010) accross climatic gradients within the same forest ecosystem.

We targeted fungi, since they play primary roles in the depolymerisation, decay, and mineralization of nutrients from organic matter, especially in acidic soils (Strickland and Rousk, 2010). Furthermore, ectomycorrhizal fungi help plants uptake nitrogen (N) (Marschner and Dell, 1994), especially in organic forms (Finlay et al., 1992). N-fixing bacteria and ammoniaoxidizing bacteria were also targeted for their respective roles as major contributors of $\mathrm{N}$ into forest ecosystems (Vitousek and Howarth, 1991; Glick et al., 1999) and as microbes catalyzing most nitrification in forest soils (Prosser, 2007). Nitrogen is the major limiting nutrient in North American forests; its availability is closely knit to productivity (Vitousek and Howarth, 1991) and its cycling in both plants and microbes is most likely an adaptive trait. Preferential uptake of specific $\mathrm{N}$-forms by tree species or genotypes (Gijsman, 1991; Turner et al., 1993) is likely a result of co-adaption of tree physiology with predominant microbial nutrient-cycling regimes.

This study focused on eastern Vancouver Island, BC, Canada located in the Coastal South Pacific Cordilleran ecoclimatic region (Ecoregions Working Group, 1989), dominated by podzolic soils and the cool temperate wet forests of the $\mathrm{WH}$ and DFBEC zones (Meidinger and Pojar, 1991). The east coast of southern Vancouver Island lies within the rainshadow of the Insular Mountains and Olympic Peninsula and is transitional between the WH and DF zones (Supplementary Table S1). The transition zone has been predicted to shift westward with climate change (Hamann and Wang, 2006). Relatively recent disturbances and logging have produced similar-aged mature Douglas-fir stands at sites spanning the range of these BEC zones, providing a unique opportunity to test the biogeography of microbial communities in field sites with similar overstory vegetation composition but different moisture and temperature regimes.

The main objectives of this study were to: (1) determine the biogeography of forest floor and mineral soil microbial communities of interest in similar ecosystems but spanning moisture and temperature gradients along the east coast of Vancouver Island; (2) identify primary in situ microclimatic and edaphic and vegetation characteristics contributing to microbial community composition and structure.

\section{Materials and Methods}

\section{Field Sites and Microclimate Monitoring}

Forest floor and mineral soil samples were taken from established sites where microclimate has been continuously measured (Saunders et al. unpublished data). Sites were located in zonal WH, DF or Transitional (TR) BEC zones at southern (s), central (c), and northern (n) latitudes between the 48th and 50th parallel (Table 1; Figure 1A). Each site is within a mesic mature or old Douglas-fir dominated stand. Four rectangular plots (ca. $\left.2.5 \mathrm{~m}^{2}\right)$ were set up at random cardinal points and distances $(<23 \mathrm{~m})$ from the microclimate station at each site (Figure 1B).

Air and soil temperature as well as soil moisture was logged hourly using Ibuttons (Maxim Integrated, San Jose, CA, USA) and thermocouples and probes connected to a CR10 data logger (Campbell Scientific, Logan, UT, USA), installed either $30 \mathrm{~cm}$ above the forest floor or buried $30 \mathrm{~cm}$ deep. Three years of moisture and temperature measurements (air and soil) were used to assess microclimates. Vegetation (percent cover of understory species; Supplementary Table S2) and soil edaphic characteristics (see below) of each plot was also recorded. The percent canopy cover of trees ( $>10 \mathrm{~m}$ height) and shrubs $(0-10 \mathrm{~m}$ height), and ground cover of herbs, seedlings and moss were surveyed at the site level to evaluate similarity of forest stand vegetation and litter input (Supplementary Table S4).

\section{Soil Sampling and Preparation}

To compare the diversity and structure of microbial communities along temperature and moisture gradients, soils were sampled from four replicate plots at each site. Forest floor and mineral soils were sampled once, in September 2011. Composite forest floor ( $\sim 2 \mathrm{~cm}$-depth) and mineral soil $(10 \mathrm{~cm}$-depth) samples were collected using a 5.0-cm-diam. core sampler. Forest floors were mainly mors and composed of a thin layer of litter with underlying $\mathrm{F}$ and $\mathrm{H}$ layers, at times with intermixed moss, 
TABLE 1 | Site location and mean annual microclimatic variables measured from June 15th, 2010 to December 14th, 2012.

\begin{tabular}{|c|c|c|c|c|c|c|c|c|c|}
\hline Transect & Zone & Latitude & Longitude & $\begin{array}{l}\text { Elevation } \\
\text { (m) }\end{array}$ & $\begin{array}{c}\text { MS (\%) } \\
\left.\text { (MS }_{\min }, \mathrm{MS}_{\max }\right)\end{array}$ & $\begin{array}{c}\text { TA }\left({ }^{\circ} \mathrm{C}\right)^{\mathrm{b}} \\
\left(\mathrm{TA}_{\min }, \mathrm{TA}_{\max }\right)\end{array}$ & $\begin{array}{c}\mathrm{TS}\left({ }^{\circ} \mathrm{C}\right)^{\mathrm{a}} \\
\left(\mathrm{TS}_{\min }, \mathrm{TS}_{\max }\right)\end{array}$ & $\begin{array}{c}\mathrm{DD}^{\mathrm{c}} \\
\left({ }^{\circ} \mathrm{C} \text { days }\right)\end{array}$ & $\begin{array}{l}\text { PET }^{d} \\
(\mathrm{~mm})\end{array}$ \\
\hline \multirow[t]{3}{*}{ South } & DF & $N 48^{\circ} 28^{\prime} 30.4^{\prime \prime}$ & W $123^{\circ} 28^{\prime} 58.8^{\prime \prime}$ & 75 & $10.8(0.3,24.9)$ & $9.3(-7.7,32.5)$ & $9.8(2.3,17.1)$ & 3245 & 437 \\
\hline & TR & $N 48^{\circ} 27^{\prime} 18^{\prime \prime}$ & W $123^{\circ} 34^{\prime} 44.9^{\prime \prime}$ & 194 & $11.2(2.3,29.6)$ & $8.1(-11.1,30)$ & $8.0(-1.2,15)$ & 2725 & 429 \\
\hline & WH & $\mathrm{N} 48^{\circ} 34^{\prime} 05.2^{\prime \prime}$ & W $123^{\circ} 39^{\prime} 46.3^{\prime \prime}$ & 239 & $11.4(2.5,29.6)$ & $8.3(-8.9,28.8)$ & $7.9(1.7,18.3)$ & 2964 & 435 \\
\hline \multirow[t]{3}{*}{ Central } & DF & N $48^{\circ} 51^{\prime} 03.8^{\prime \prime}$ & W $123^{\circ} 37^{\prime} 13.3^{\prime \prime}$ & 134 & $8.5(1.1,24.7)$ & $10.5(-10,28.5)$ & $9.6(2.3,17.4)$ & 3462 & 461 \\
\hline & $\mathrm{TR}$ & $\mathrm{N} 48^{\circ} 45^{\prime} 32.6^{\prime \prime}$ & W $123^{\circ} 47^{\prime} 43.3^{\prime \prime}$ & 104 & $7.6(0,17.3)$ & $9.7(-7.7,30.3)$ & $9.3(1.3,17.2)$ & 3344 & 456 \\
\hline & WH & $N 48^{\circ} 50^{\prime} 15.5^{\prime \prime}$ & $W 123^{\circ} 49^{\prime} 23.5^{\prime \prime}$ & 236 & $10.6(1,22.8)$ & $8.8(-8.1,37)$ & $8.2(0.7,15.2)$ & 2891 & 444 \\
\hline \multirow[t]{3}{*}{ North } & DF & $N 49^{\circ} 25^{\prime} 30.0^{\prime \prime}$ & W $124^{\circ} 40^{\prime} 00.3^{\prime \prime}$ & 32 & $10.9(1,41.6)$ & $8(-9.9,25.4)$ & $9.2(0.5,15.7)$ & 3090 & 431 \\
\hline & TR & $N 49^{\circ} 26^{\prime} 47.8^{\prime \prime}$ & W $124^{\circ} 44^{\prime} 06.3^{\prime \prime}$ & 69 & $11(0,49.3)$ & $10.1(-7.2,31.3)$ & $9.5(2.2,17.8)$ & 3489 & 452 \\
\hline & $\mathrm{WH}$ & N $49^{\circ} 28^{\prime} 22.4^{\prime \prime}$ & W 124 $48^{\prime} 39.2^{\prime \prime}$ & 34 & $11.4(0.9,28.1)$ & $8.9(-10.5,28.6)$ & $8.8(1.9,15.2)$ & 3046 & 443 \\
\hline
\end{tabular}

Values in parentheses indicate mean annual minimum and maximum values.

a Mean annual soil moisture (MS) and temperature (TS) $30 \mathrm{~cm}$ below-ground.

${ }^{b}$ Mean annual air temperature $30 \mathrm{~cm}$ above-ground.

${ }^{c}$ Degree days with $0^{\circ} \mathrm{C}$ threshold, calculated from mean monthly temperature.

dPotential evapotranspiration from May to September, calculated from mean monthly temperature using Thornthwaite method.
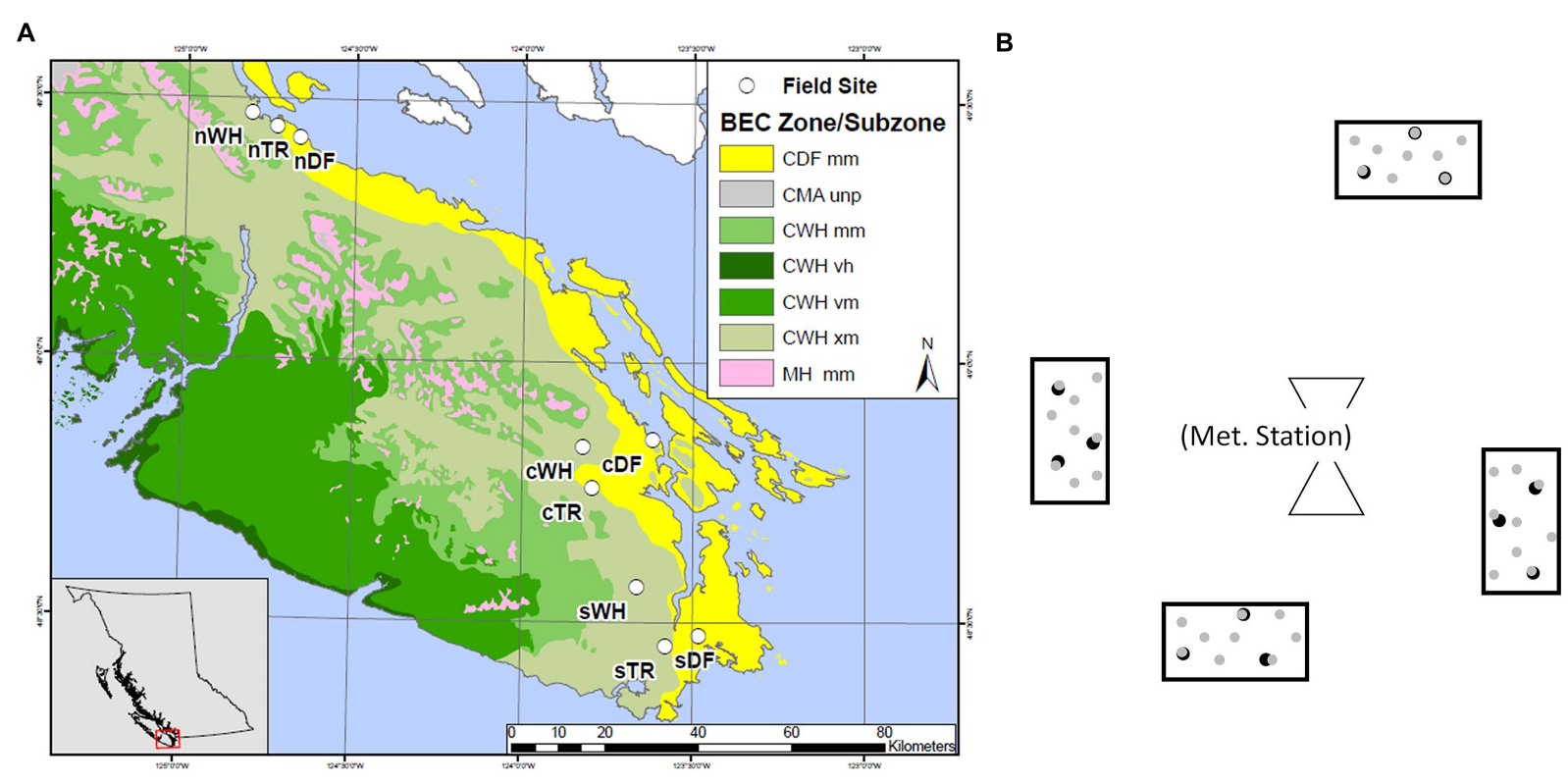

FIGURE 1 | Layout of southern (s), central (c) and northern (n) transects, each hosting zonal sites in WH, DF and transitional (TR) biogeoclimatic zones. Map colors depict coastal Douglas-fir (CDF), coastal Western Hemlock (CWH), coastal Mountain-Heather Alpine undifferentiated and parkland (CMA unp) and Mountain Hemlock (MH) Biogeoclimatic (BEC) zones as well as moist maritime ( $\mathrm{mm}$ ), very wet hypermaritime (vh), very wet maritime (vm) and very dry maritime $(\mathrm{xm})$ subzones $(\mathbf{A})$. General plot layout surrounding a meteorological station at a given site, with depiction of the nine forest floor $(\bullet)$ and three mineral soil $(\bullet)$ cores in each plot (B).

and generally distinct interfaces with mineral soil. To reduce the influence of $\alpha$-diversity (Martiny et al., 2006; Chowdhury et al., 2011), nine forest floor samples (randomly distributed cores at least $30 \mathrm{~cm}$ apart) and three mineral soil samples were collected at each plot (Figure 1). Mineral soil cores were collected beneath three of the nine forest floor sample holes, avoiding those exposing large roots and underlying rock. Composite forest floor $\left(177 \mathrm{~cm}^{2}\right.$ total surface area) and mineral soil $\left(590 \mathrm{~cm}^{3}\right.$ total volume) samples, pooled by plot, were kept in plastic bags on ice in a cooler or refrigerated at $4^{\circ} \mathrm{C}$ up to $36 \mathrm{~h}$ prior to processing.
Each composite sample was separated into coarse and fine particulate fractions by sieving through sterile $8-\mathrm{mm}$ sieves (forest floor organic samples) or 2-mm sieves (mineral soil samples). Coarse mineral soil fractions were further separated into live roots, wood pieces, and gravel. The fine fractions of each sample were homogenized with gloved hands and subsamples $(0.25 \mathrm{~g})$ were stored at $-20^{\circ} \mathrm{C}$ for DNA extraction (see below). Dry weight was calculated by air-drying samples for 3 weeks and correcting for moisture content of oven-dried (forest floor samples at $70^{\circ} \mathrm{C}$ and mineral soils at $105^{\circ} \mathrm{C}$ ) samples $(10 \mathrm{~g}$ for fine forest floor and $20 \mathrm{~g}$ for fine mineral soils). 
The $\mathrm{pH}$ of air-dried material was measured in aqueous $2 \mathrm{M}$ $\mathrm{CaCl}_{2}$ (Kalra and Maynard, 1991) using $10 \mathrm{~g}$ subsamples of finepulverized forest floor (using a Polymix hammer mill model PX-MFC 90D, Kinematica, Switzerland) or fine mineral soil. Fine-pulverized forest floor or fine-ground mineral soil (using a Siebtechnik GmbH ring grinder, Germany) was dried overnight at $70^{\circ} \mathrm{C}$ and $\sim 10 \mathrm{mg}$ used for subsequent carbon (C) and $\mathrm{N}$ analyses with an elemental combustion system (model ECS 4010 equipped with a dual-column system consisting of a standard reactor packing for $\mathrm{C}$ and $\mathrm{N}$ followed by a reduction reactor packing, Costech Analytical Technologies Inc, USA). Final \%C and $\% \mathrm{~N}$ (mass fraction $\%$ in fine soil) of mineral soil samples were corrected for moisture content at $105^{\circ} \mathrm{C}$.

\section{DNA Extraction and PCR-DGGE}

DNA was extracted from soil and forest floor samples using the PowerLyser ${ }^{\mathrm{TM}}$ PowerSoil $^{\circledR}$ DNA Isolation Kit (MoBio Laboratories Inc., USA) according to manufacturer's protocol. In order to ensure DNA quantity and quality, extracted DNA was analyzed spectrophotometically using a ND1000 spectrophotometer (NanoDrop products, USA) and stored at $-20^{\circ} \mathrm{C}$ prior to PCR. DNA concentrations and $\lambda$ absorbance ratios of 230/280 and 230/260 were compared among sampling sites to ensure unbiased extraction of total DNA.

All primer sets used in this study include a GC-clamp to stabilize the melting behavior of amplified PCR fragments during DGGE (Table 2; Sheffield et al., 1987; Kowalchuk et al., 1997). A T-gradient thermocycler (Biometra GmbH, Goettingen, Germany) was used for all PCR steps. Cycling conditions for amplification of the NifH gene, used to target bacterial nitrogenase genes, was performed according to modifications by Burgmann et al. (2005) of a protocol by Widmer et al. (1999). Amplification of the $A m o A$ gene, for screening of ammoniaoxidizing bacteria (McTavish et al., 1993; Klotz and Norton, 1995; Rotthauwe et al., 1997; Norton et al., 2002; Junier et al., 2009), was performed according to a protocol by Nicolaisen and Ramsing (2002). Amplification of fungal-specific partial fragments of $18 \mathrm{~S}$ rDNA was performed according to the method of Vainio and Hantula (2000) and Vainio et al. (2005). Pooled DNA from all mineral soil or forest floor samples was used as a PCR template for DGGE ladders, allowing cross-gel comparisons of band migration distances. DGGE was performed using a D-Code ${ }^{\mathrm{TM}}$ Universal Mutation Detection system (BioRad Laboratories Ltd., Mississauga, ON, Canada) and conditions outlined in Table 2. Gels were electrophoresed for $18 \mathrm{~h}$ at $60^{\circ} \mathrm{C}$ and $80 \mathrm{~V}$, while submerged in $1 \mathrm{X}$ TAE buffer ( $40 \mathrm{mM}$ Tris, $20 \mathrm{mM}$ acetic acid and $1 \mathrm{mM}$ EDTA at $\mathrm{pH}$ 8.3), and subsequently stained for 20 min with SYBR ${ }^{\circledR}$ Gold (Invitrogen, Canada). Bands were visualized using a transillumination system (Syngene ChemiGenius Q Bio-imaging system) and identified using the rolling disk method in GeneTools (Syngene, Frederick, MD, USA) computer software.

\section{Data and Statistical Analyses}

All statistical analyses were performed using R v3.1.0 ( $R$ Development Core Team, 2014).
Concentrations and $\lambda$ absorption ratios (260/280 and 260/230) of DNA extracted from forest floor and mineral soil samples were modeled in response to transect, zone and their interactions, as well as in response to soil characteristics and vegetation cover, to ensure DNA extraction was not biased by site or environmental factors.

Polymerase chain reaction-denaturing gradient gel electrophoresis fingerprinting cannot detect taxa with proportionally low abundances $(<1 \%)$, but did not preclude the use of diversity indexes to observe trends of targeted functional groups (Muyzer and Smalla, 1998; Fromin et al., 2002; Fierer and Jackson, 2006; Monroy et al., 2012). Shannon's diversity (Equation 1), richness (Equation 2), and Pielou's evenness (Equation 3) of target microbial functional groups were calculated for each plot sample, where $n_{i}=$ peak height of the $\mathrm{i}^{\text {th }}$ DGGE band, $\mathrm{N}=$ sum of peak heights for all bands, and $\mathrm{S}=$ total number of bands, and used for analysis of community structure.

$$
\begin{aligned}
H^{\prime} & =-\sum\left[\frac{\mathrm{n}_{\mathrm{i}}}{\mathrm{N}}\right] \log \left[\frac{\mathrm{n}_{\mathrm{i}}}{\mathrm{N}}\right] \\
d & =\frac{[\mathrm{s}-1]}{\log [\mathrm{N}]} \\
J & =\frac{H^{\prime}}{\log [\mathrm{S}]}
\end{aligned}
$$

OTUs found in each sample were also compiled into presence/absence matrices for analysis of community composition.

Constrained and partial-constrained (conditioned) multivariate ordinations were used to differentiate the effects of climatic factors, edaphic characteristics, and spatial distribution on both microbial community composition and structure variables using the 'vegan' package (Oksanen et al., 2015). Constrained redundancy analysis (RDA) or constrained correspondence analysis (CCA) was selected for each multivariate model when detrended correspondence analysis of response variables showed a small $(<1)$ or large $(>2)$ range distribution, respectively (Legendre and Birks, 2012). In RDA models, responses were power-transformed when appropriate, to ensure multivariate normality based on skewness (Kankainen et al., 2007). For each model, constraints were selected by backward and forward stepwise elimination of least significant factors based on Akaike Information Criterion (AIC)-like statistics (Godinez-Dominguez and Freire, 2003). The significance of whole models or individual constraints in explaining total Inertia was analyzed by comparing Chi-squared distances (CCA) or Euclidean distances (RDA) of full and reduced models, using permutation tests for RDA or CCA (9999 permutations, pseudo- $F$ tests); where constraints are assessed all simultaneously or sequentially. Responses were each scaled to unit variance in all multivariate analyses (see Oksanen et al., 2015 for further details). Microbial functional groups were treated both individually and as a whole, to explore correlated effects between communities. When treating functional groups separately, non-existent community structure 
TABLE 2 | Polymerase chain reaction primer sequences and associated DGGE conditions used in this study.

\begin{tabular}{|c|c|c|c|c|c|c|}
\hline $\begin{array}{l}\text { Target } \\
\text { Organisms }\end{array}$ & Primer & Sequence $\left(5^{\prime} \rightarrow 3^{\prime}\right)^{a}$ & $\begin{array}{c}\text { Product } \\
\text { Size }(b p)^{b}\end{array}$ & $\begin{array}{l}\text { (Bis)acrylamide } \\
\% \text { in DGGE gels }\end{array}$ & $\begin{array}{l}\text { Denaturing } \\
\text { gradient }^{c}\end{array}$ & Reference \\
\hline Fungi & $\begin{array}{l}\text { 18S FF390 } \\
\text { 18S FR1 }\end{array}$ & $\begin{array}{l}\text { CGA TAA CGA ACG AGA CCT } \\
\text { AIC CAT TCA ATC GGT AIT }\end{array}$ & 390 & $7 \%$ & $30-60 \%$ & $\begin{array}{l}\text { Vainio and Hantula, } \\
2000\end{array}$ \\
\hline $\begin{array}{l}\beta \text {-Proteobacteria } \\
\text { Ammonia-oxidizing bacteria }\end{array}$ & $\begin{array}{l}\text { AmoA 1F' } \\
\text { AmoA 2 } \mathrm{R}^{\mathrm{e}}\end{array}$ & $\begin{array}{l}\text { GGG GHT TYT ACT GGT GGT } \\
\text { CCC CTC KGS AAA GCC TTC TTC }\end{array}$ & $\sim 490$ & $8 \%$ & $45-70 \%$ & $\begin{array}{l}\text { Widmer et al., 1999; } \\
\text { Burgmann et al., } 2005\end{array}$ \\
\hline Free-living diazotrophs & $\begin{array}{l}\text { NifH-uni ForA } \\
\text { NifH-uni ForB } \\
\text { NifH-uni Rev }\end{array}$ & $\begin{array}{l}\text { GCI WTI TAY GGN AAR GGN GG } \\
\text { GGI TGY GAY CCN AAV GCN GA } \\
\text { GCR TAI ABN GCC ATC ATY TC }\end{array}$ & 371 & $7 \%$ & $45-70 \%$ & $\begin{array}{l}\text { Nicolaisen and } \\
\text { Ramsing, } 2002\end{array}$ \\
\hline
\end{tabular}

a Degeneracy is indicated by standard conventions: H, not G; Y, C or T; K, G or T; S, C or G; W, A or T; N, A, C, G or T; R, A or G; B, not A.

${ }^{\mathrm{b}}$ Based on estimates from the literature.

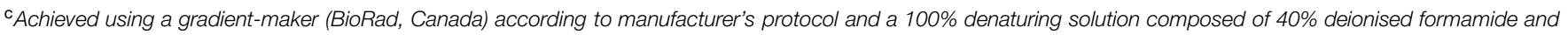
7 M urea, as defined by Muyzer et al. (1993).

'GC-clamp: CCC CCG CCG CGC GCG GCG GGC GGG GCG GGG GCA CGG GCC G.

eGC-clamp: CGC CGC GCG GCG GGC GGG GCG GGG GC.

${ }^{f}$ GC-clamp: GC CCG CCG CGC GCG GCG GGC GGG GCG GGG GCA CGG GGG.

indices, resulting from the absence of OTUs in a particular sample, were imputed using the 'missMDA' package (Josse et al., 2011) to allow for analysis without the influence of these values.

First, associations between edaphic characteristics or vegetation cover, and climate were assessed, along with those directly between microbial groups. Edaphic characteristics used in multivariate models [fine soil $\% \mathrm{C}$ and $\% \mathrm{~N}$ and ratios $(\mathrm{C} / \mathrm{N}), \mathrm{pH}$, and coarse and fine fraction mass and ratio $(\mathrm{Co} / \mathrm{F})$; Figure 3; Supplementary Tables $\mathrm{S3}, \mathrm{S} 7 \mathrm{c}$ and S8c] were those significantly different between at least two sites using Tukey HSD univariate pairwise comparisons. In univariate models, edaphic characteristics were transformed, when appropriate, to pass the Shapiro-Wilk normality test. Climate variables included soil moisture variables [mean (MS), minimum $\left(\mathrm{MS}_{\min }\right)$, and maximum $\left(\mathrm{MS}_{\max }\right)$ annual soil moisture], PET, DD, and temperature variables [mean (TA), minimum $\left(\mathrm{TA}_{\min }\right), \quad$ maximum $\left(\mathrm{TA}_{\max }\right)$ annual air and soil (TS, $\mathrm{TS}_{\min }, \mathrm{TS}_{\max }$ ) temperatures; Table 1].

To assess the significant differences in beta-diversity among sites, OTU composition (presence/absence) or community structure (Shannon's diversity - $H^{\prime}$, richness $d$, and Pielou's evenness - $J$ ) was analyzed in response to (constrained by) latitude, zone and their interaction. Responses to vegetation cover and edaphic characteristics, climatic factors, or spatial distance were then independently performed to assess best continuous predictors of community composition and structure at various scales, and for comparison with site-level categorical analyses. Spatial distance was parameterized by transforming geospatial coordinates at the plot level into 18 dimensions using PCNM (Borcard et al., 2004). Partial-constrained multivariate ordinations of microbial communities in response to climatic variables (constraints) omitting the effects of edaphic and vegetation heterogeneity (conditions) was also performed, using only factors selected in non-conditioned models, in order to separate correlated environmental effects and assess direct influence of climate on microbial biogeography. Significant climatic and edaphic variables were treated as combined environmental factors in models isolating the effects of spatial distance, as first described by Borcard et al. (1992; Legendre et al., 2005).

\section{Results}

\section{DNA Quantity and Quality}

DNA extractability and quality of both mineral soil and forest floor samples (Supplementary Table S5) did not significantly differ among sites $(P>0.05)$, and was not significantly affected by edaphic characteristics or vegetation cover $(P>0.05)$. Technical replicates of our PCR-DGGE process (Supplementary Figure S1) demonstrated reproducible screening of abundant OTUs of each targeted functional groups.

\section{Vegetation Cover and Edaphic Characteristics}

Canopy/ground cover of trees, shrubs and herbs did not significantly differ with latitude or zone, even when only considering dominant tree species or a single vegetation stratum (Permutation test for RDA $P>0.05$; data not shown). Nonetheless, canopy cover is less dominated by Douglas-fir and more by Western redcedar and Western hemlock in sTR, nTR and nWH sites (Supplementary Figure S2A). Moss-species composition changed with latitude (Permutation test for RDA under reduced model $P=0.006$; Supplementary Figure S2B), however, total moss cover was not significantly associated with latitude or zone (ANOVA $P>0.05$ ).

Understory vegetation cover at the plot-level was generally quite similar among sites (Supplementary Table S2) and did not show clustering representative of changes in dominant tree cover at the site-level (Figure 2). Greater proportion of moss and vanilla leaf cover was associated with most nTR plots, and the relatively high $\mathrm{MS}_{\max }$ at this site (Figure 2; Supplementary Table S6). No relationships were found between forest floor characteristics and vegetation cover (Permutation test for CCAs $P>0.05$; see Supplementary Table S3 for characteristics of soil layers). To 


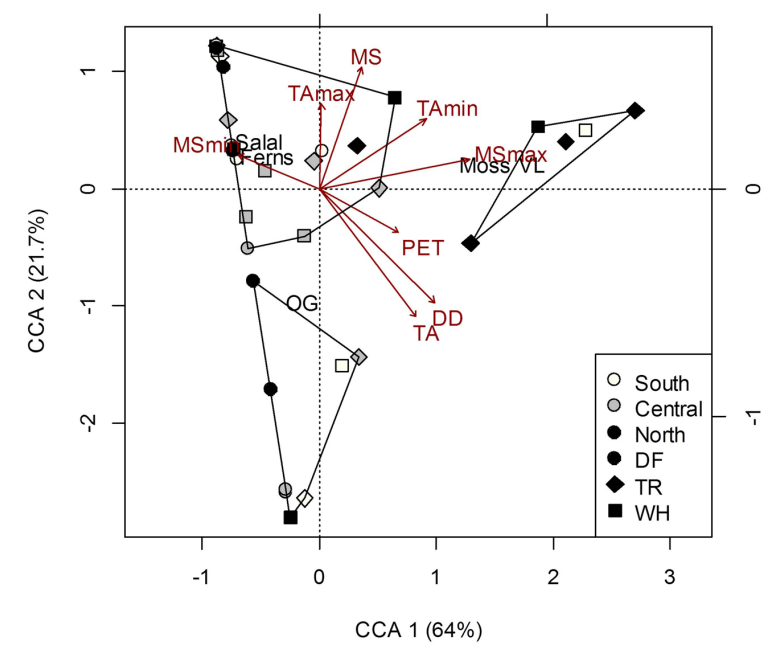

FIGURE 2 | Constrained correspondence analysis (CCA) of plot vegetation cover [Salal, Gaultheria shallon; Ferns, Polystichum munitum; Oregon grape (OG), Mahonia aquifolium; Vanilla leaf (VL), Achlys triphylla; Moss] in response to climate. Polygons represent k-means clustering using CCA components 1 and 2. All responses were scaled to unit variance. Percent inertia explained by each CCA component is in parenthesis next to axis label. Climate accounted for $34.7 \%$ of plot vegetation cover $(P<0.05)$, however, only $\mathrm{MS}_{\max }$ and PET were significant factors.

some extent $(26.7 \%$ of total inertia; Permutation test for CCA $P=0.003)$, more acidic mineral soils were associated with more vanilla leaf and moss, and also less salal, Oregon grape (OG) and fern cover; greater aeration $(\mathrm{Co} / \mathrm{F}$ ratio) was associated with $\mathrm{OG}$ cover, despite $\mathrm{pH}$ being negatively correlated with the $\mathrm{Co} / \mathrm{F}$ ratio $(r=-0.49 ; P=0.002)$.

Edaphic characteristics differed slightly among sites, most prominently C and N (Figure 3, Supplementary Table S6). C and $\mathrm{N}$ concentrations were highly correlated in all samples $(r=0.92$ and 0.94 for forest floor and mineral soil, respectively; $P<0.001$ ). Climate explained more of the variance in edaphic characteristics in mineral soil (73\%) than in forest floor (56.7\%) (Supplementary Table S6), indicating more within-site substrate homogeneity in this layer and a potentially stronger relationship to local climate variables. Greater $\mathrm{C}$ and $\mathrm{N}$ in mineral soil were associated with lower $\mathrm{TA}_{\min }$ and $\mathrm{MS}_{\max }$ (Figure 3). In both forest floor and mineral soil samples, $\mathrm{pH}$ was highest in DF (5.03 and 5.10, respectively), intermediate in TR (4.47 and 4.62, respectively) and lowest in WH sites (4.27 and 4.37, respectively; Supplementary Table S3). Across zones, forest floor $\mathrm{pH}$ was lowest in $\mathrm{n}$ - and highest in c-transects (Supplementary Table S3).

\section{Microbial Communities in Forest Floor}

The direct climatic influences on forest floor microbial community structure along the observed temperature and moisture gradients, as the influences of TA and $\mathrm{TA}_{\text {min }}$ on fungal and $A m o A$ bacteria communities were confounded by the effects of forest floor N (Supplementary Table S7d). Both TA and N had similar effects on fungal community structure, mainly positive correlations with fungal diversity and evenness, and negative correlations with richness (Figure 4A; see Supplementary Table S9 for mean OTUs and Shannon's diversity indices by site). A rise in $A m o A$ bacteria richness and evenness, associated with more OTUs in sWH, cDF and $\mathrm{nDF}$ samples, can be attributed to generally lower PET and $\mathrm{TA}_{\max }$ at these sites (Supplementary Table S7b). Fungal community indices increased with increasing $\mathrm{TA}_{\max }$ and decreasing DD, but these effects were confounded by $\mathrm{pH}$ and $\mathrm{N}$ (Figure 4A; Supplementary Table S7d). Plot differences in the NifH bacteria community structure were not associated with latitude or zone, climate or plant cover, but all structural indexes increased with soil C (Supplementary Tables S7a-c) and accounted for $25.9 \%$ of trends in $A m o A$ community sturcture.

The overall composition of microbial communities in forest floors was significantly related to $\mathrm{MS}_{\min }$, DD and temperature extremes, which also separate northern sites from central and southern sites (Figure 5A; Supplementary Table S7b). Fungal composition was mainly responsible for microbial community associations with $\mathrm{TA}_{\min }$ and $\mathrm{MS}_{\min }$ (Figure 5A; Supplementary Table S7b) while both $A m o A$ and $N i f H$ bacteria composition were associated with $\mathrm{TA}_{\max }$. For the latter, effects were confounded by associations with moss cover and fine fraction content (Supplementary Table S7d). Yet, fungal composition accounted for $91.6 \%$ of $\mathrm{NifH}$ bacteria composition in forest floors $(P=0.03)$. Interestingly, the most significant climatic factor (DD) and edaphic characteristic $(\mathrm{pH})$ describing overall microbial composition did not appear as influential factors when functional groups were examined separately (Figure 5A; Supplementary Tables S7b,c); this was possibly an artifact of differences in the number of OTU's in each group (Supplementary Table S9). Nonetheless, analysis of overall microbial composition clearly isolates two clusters of n-transect samples from other sites (Figure 5A).

Although vanilla leaf and moss were the vegetation covers which most differentiated sites, only moss cover was significantly correlated to a microbial community response, namely NifH bacteria composition (Supplementary Tables S7b and S8b). Salal cover was significantly linked to $A m o A$ bacteria composition when treating functional groups separately (Supplementary Tables S7b and S8b).

\section{Microbial Communities in Mineral Soil}

As with forest floor samples, the confounding effects of edaphic characteristics and vegetation cover made it difficult to directly associate the structure of microbial communities in mineral soil with climatic variables. Community structure differed among latitudes and zones, mainly due to differences in fungi across latitudes and in $\mathrm{NifH}$ bacteria across latitude and zones. The only significant association directly between microbial communities in mineral soil was fungal community structure accounting for $21.6 \%$ of $\mathrm{NifH}$ community structure $(P=0.03)$. Dryer climates were generally associated with less fungal richness, versus more richness, diversity and evenness of $\mathrm{NifH}$ bacterial communities (Supplementary Tables S8 and S9). Fungal diversity and evenness differed between southern and northern sites, mostly because of differences between sDF and nDF-nTR sites. Fungal diversity and evenness were 28 and 22\% greater, respectively, in $\mathrm{sDF}$ than $\mathrm{nDF}$ sites $(p<0.01$ and $p=0.011$, 

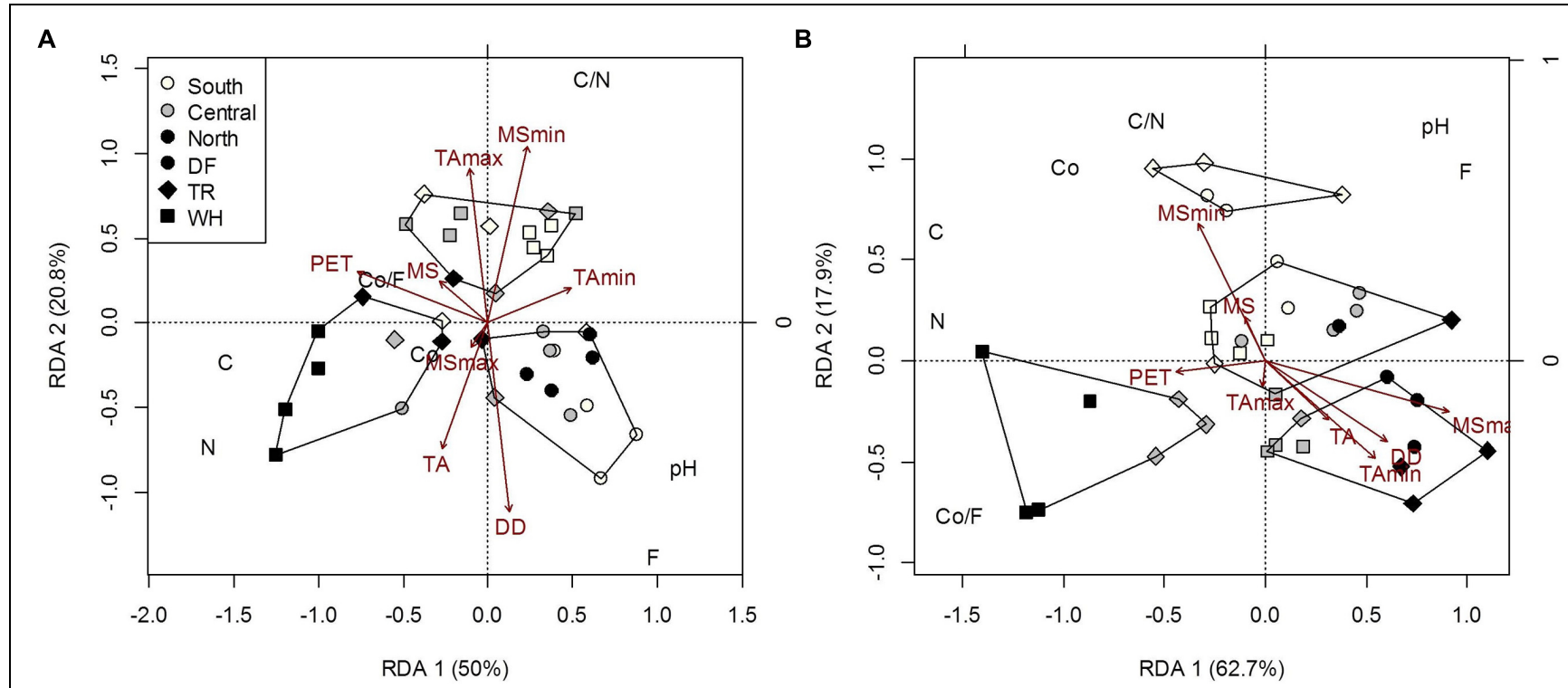

FIGURE 3 | Constrained RDA of forest floor (A) and mineral soil (B) edaphic characteristics [Co, coarse fraction content (g); F, fine fraction content (g); Co/F, coarse to fine ratio (g/g); $\mathrm{N}$, nitrogen concentration (\%); $\mathrm{C}$, carbon concentration (\%); $\mathrm{C} / \mathrm{N}$, carbon to nitrogen ratio; pH] of plot samples across latitudes and zones, constrained by climatic variables. Polygons represent k-means clustering using RDA components 1 and 2 . All responses were scaled to unit variance. Percent inertia explained by each RDA component is in parenthesis next to axis label. Climate accounted for 56.7 and $73 \%$ of forest floor and mineral soil edaphic characteristics, respectively $(P<0.05)$. MS $\max _{\text {ax }}$ and TA were not significant factors in the forest floor model, while MS $\mathrm{min}_{\text {, }}$ PET and DD were not in the mineral soil model.
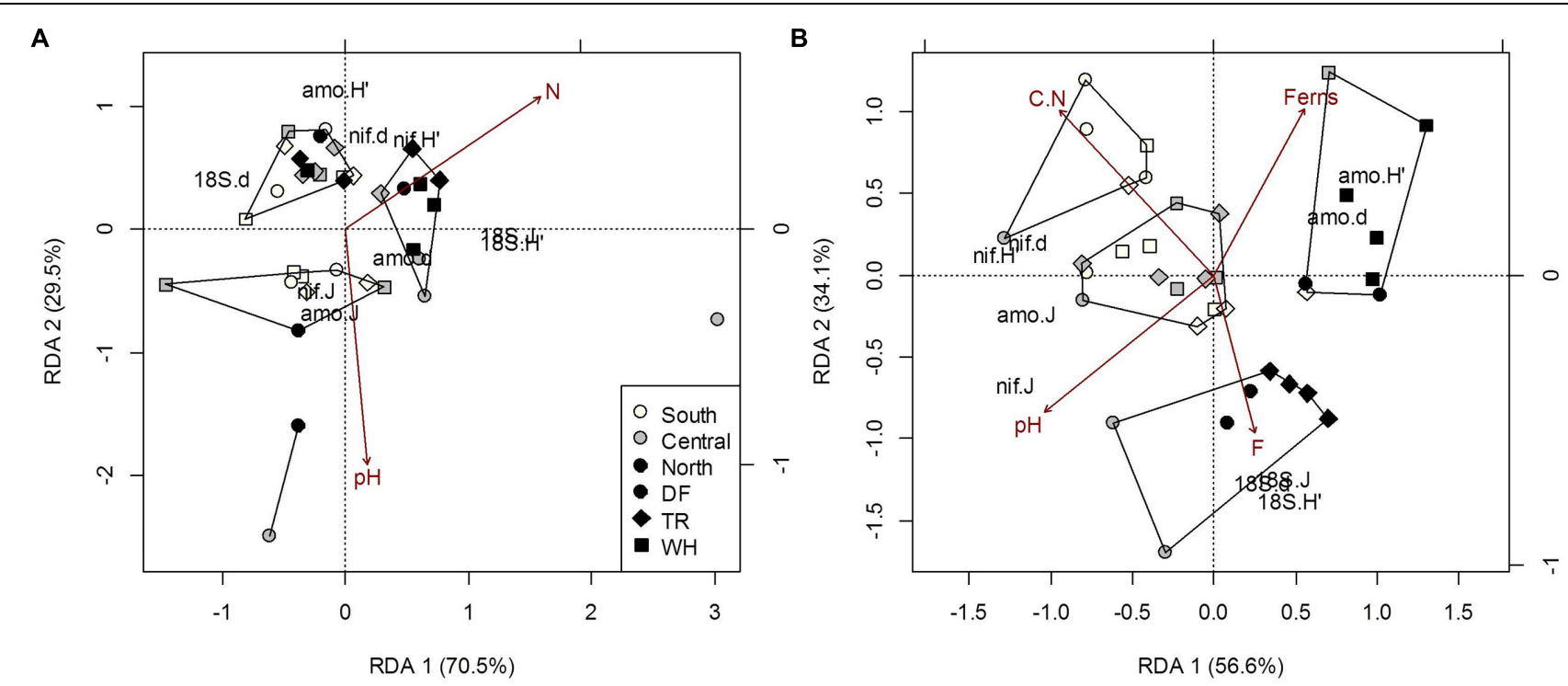

FIGURE 4 | Constrained RDA of microbial community structure (H', diversity; d, richness; J, evenness) from forest floor (A) and mineral soil (B) samples in response to edaphic characteristics and vegetation cover (constraints). Polygons represent k-means clustering using RDA components 1 and 2. All responses were scaled to unit variance. Percent inertia explained by each CCA component is in parenthesis next to axis label. Microbial functional groups are designated by prefixes 18S, NifH and AmoA for target fungal, nitrogen-fixing and ammonia-oxidizing bacteria communities, respectively. Selected constraints for forest floor samples include $\mathrm{pH}$ and nitrogen concentration $(\mathrm{N})$, while those for mineral soil samples include fern cover (Ferns), carbon to nitrogen ratio (C.N), pH and the fine fraction content $(F)$. Constraints accounted for $12.2 \%$ and $34.7 \%$ of microbial community structure in forest floor and mineral soils respectively $(P<0.05)$.

respectively). These site differences cannot be solely attributed to climate, due to negative correlations with $\mathrm{C} / \mathrm{N}(r=-0.49$; $P=0.002)$ and positive correlation with fine fraction content $(r=0.62 ; p=0.05)$ with $\mathrm{MS}_{\max }$ (Figure 3). Northern sites also differed from southern and central sites, as structural indices for $\mathrm{NifH}$ bacteria decreased with increasing latitude. Richness and evenness of NifH bacteria also differed between DF and $\mathrm{WH}$ zones (Supplementary Table S8), but the influences of MS and 

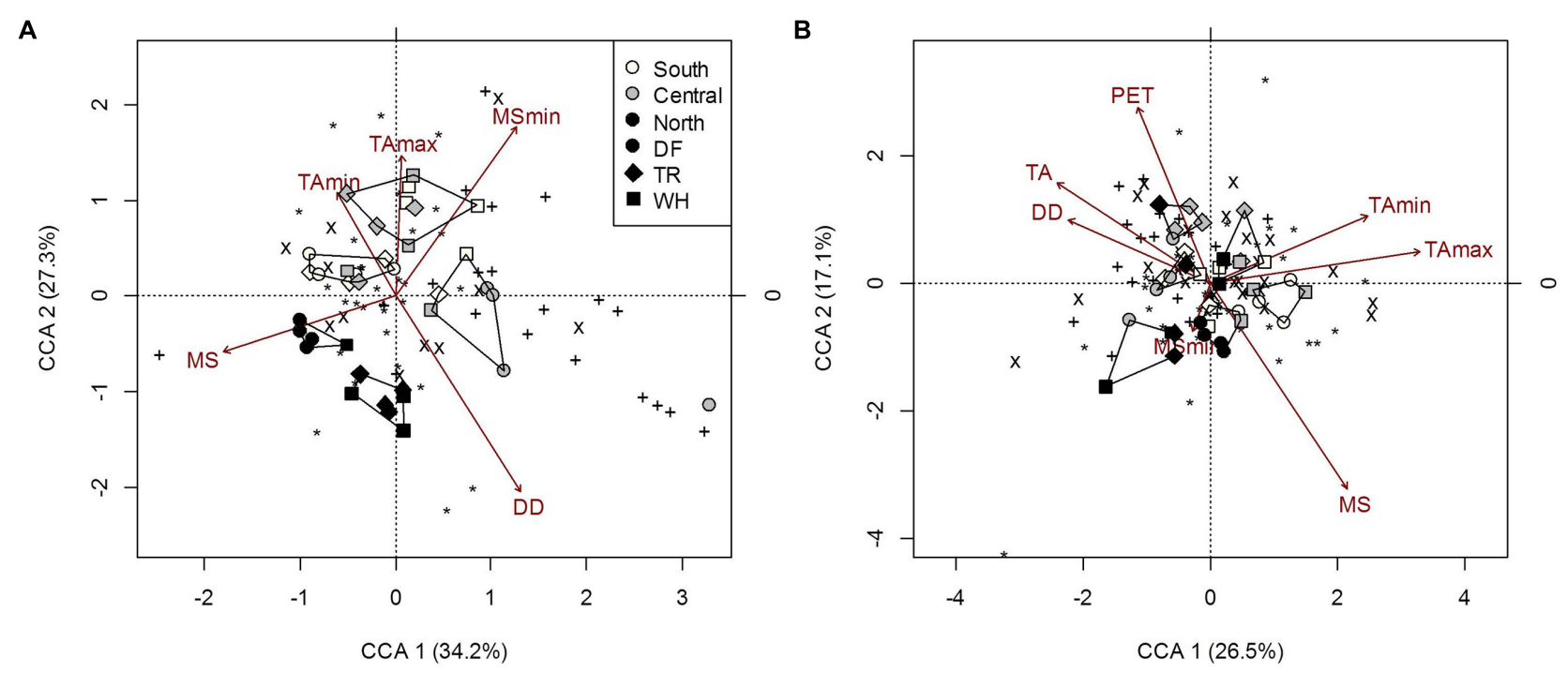

FIGURE 5 | Constrained correspondence analysis of microbial community composition from forest floor (A) and mineral soil (B) samples in response to climatic variables (constraints) omitting the effects of edaphic heterogeneity (conditions). Polygons represent $\mathrm{k}$-means clustering using CCA components 1 and 2. Black symbols each represent a unique OTU (*, 18S-FF390/FR1; $x, N$ ifH; + , AmoA). All responses were scaled to unit variance. Percent inertia

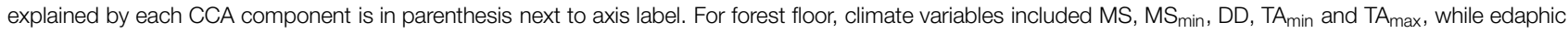
characteristics included $\mathrm{pH}$. For mineral soil, climate variables included MS, MS $\mathrm{min}_{\mathrm{n}}, \mathrm{PET}, \mathrm{DD}, \mathrm{TA}, \mathrm{TA}_{\min }$ and TA $\mathrm{A}_{\max }$, while edaphic characteristics included the fine fraction content, [N], [C] and pH. Constraints accounted for 20.4 and $23 \%$ of microbial community composition in forest floor and mineral soils respectively, while conditions accounted for 4.9 and $19.4 \%$, respectively $(P<0.001)$.

$\mathrm{MS}_{\max }$ on $\mathrm{NifH}$ communities were confounded by the effects of $\mathrm{C} / \mathrm{N}$ and $\mathrm{pH}$, respectively (Figure 4A; Supplementary Table S8). The $A m o A$ bacteria community structure did not differ significantly among sites; significant associations with DD and MS were confounded by soil $\mathrm{pH}$ and fern cover (Figure 4A; Supplementary Table S8). Fern cover, which increased with diversity and richness of $A m o A$ bacteria, was the only understory vegetation significantly correlated to community structure or composition when modeled responses included all 3 targeted functional groups (Figures $4 B$ and $5 B$ ).

The composition of microbial communities in mineral soil was primarily influenced by MS, DD, TA and $\mathrm{TA}_{\max }$ (Figure 5A; Supplementary Table S8). MS was significantly correlated with fungal and NifH OTUs (Figure 5A; Supplementary Table S8). TA $\mathrm{Tax}_{\max }$ was primarily associated with changes in fungal composition while DD and TA were associated with changes in NifH bacteria composition (Figure 5B; Supplementary Table S8). Although $\mathrm{TA}_{\min }$ correlated with fungal composition in samples, the correlation of $\mathrm{TA}_{\mathrm{min}}$ with $\mathrm{N}$ and $\mathrm{C}(r=0.44$ and $-0.41 ; P=0.007$ and 0.014 , respectively) is likely responsible for the decreased significance of this climatic factor in the overall microbial composition model when effects of edaphic characteristics are removed (Supplementary Table S8d). The composition of $A m o A$ bacterial communities changed with latitude, but this could only be attributed to changes in soil $\mathrm{pH}$ (Supplementary Tables S3 and S8). Soil pH also influenced NifH bacterial community composition, and accordingly was significantly associated with overall microbial composition (Supplementary Table S8c). Salal cover was only significantly linked to $\mathrm{NifH}$ bacteria community composition. Other edaphic characteristics influencing overall microbial composition were fine fraction content, $\mathrm{C}$ and $\mathrm{N}$, which were associated with changes in both fungal and NifH bacterial OTUs (Supplementary Table S8c).

\section{Microbial Biogeography: Spatial and Environmental}

On average, more of the variation in microbial communities was accounted for in mineral soil $(47.8 \%)$ than in forest floor (33.9\%; Table 3). Environmental variables (climate, understory cover, and edaphic characteristics) explained between 14 and 25\% of variation in microbial community structure and composition. With the exception of mineral soil community structure, that would correspond to 1.3-4.2 times the amount attributable to spatial variables or shared effects (Table 3 ). The highest explanatory power for spatial and shared effects was for mineral soil community structure (22.6 and $16.1 \%$, respectively), where $52.7 \%$ of the variance was accounted for by environmental, spatial and shared effects (Table 3). On average, shared effects explained 1.8 times more variation in community structure than composition, even though similar variables were used in all models and the number of significant variables was less in community structure models. Transformation of Easting and Northing spatial scales yielded 18 PCNM components, of which only the first five were useful in accounting for microbial biogeography (Table 3; see Supplemental Figure S3 for more details). For all microbial community responses except for community structure in forest floor, PCNM 1, which correlates with latitude $(r=0.8673, P<0.001)$, was the only remaining 
TABLE 3 | Significant environmental variables and spatial principal coordinates of neighbor matrices (PCNM) selected for modeled responses of microbial community structure and composition, and the proportion of Inertia explained by environmental variables alone (Env.), spatial variables alone and a combination of both variables (Both), as well as variance unaccounted for by each model (Unknown).

\begin{tabular}{|c|c|c|c|c|c|c|c|}
\hline \multicolumn{2}{|c|}{ Responses } & \multicolumn{2}{|l|}{ Variables } & \multicolumn{4}{|c|}{ Percent Inertia explained } \\
\hline Soil layer & Community Index & Environmental factors & Spatial PCNMs & Env. & Both & Spatial & Unknown \\
\hline \multirow[t]{2}{*}{ Forest floor } & Structure & MSmin, TA, TAmin, $N$ & 2,4 & 18.60 & 11.49 & 4.46 & 65.45 \\
\hline & Composition & MSmin, DD, TAmin, TAmax, \% salal & $1,3,4$ & 14.87 & 6.67 & 11.67 & 66.79 \\
\hline \multirow[t]{2}{*}{ Mineral soil } & Structure & MS, MSmax, Fine, DD & $1,4,5$ & 13.92 & 16.15 & 22.65 & 47.28 \\
\hline & Composition & MS, MSmin, PET, TA, pH, N, C, Fine & $1,3,4$ & 25.53 & 8.25 & 9.09 & 57.13 \\
\hline
\end{tabular}

All responses were scaled to unit variance.

significant spatial scale in models conditioned by their respective environmental variable $(P<0.05,9999$ permutations, pseudo$F$ tests). PCNM 2 was the only significant spatial component in environmentally conditioned models of forest floor community structure $(P<0.05,9999$ permutations, pseudo- $F$ tests), and did not correlate with any of our measured environmental variables.

\section{Discussion}

Fungal communities were not associated with any changes in vegetation cover, despite numerous documented plant/fungal mutualistic relationships. Very similar host availability among sites is most likely the cause (Tedersoo et al., 2012), however, shifts in fungal communities are not always mirrored by plants (Tedersoo et al., 2014). Root systems were avoided during sampling, on average making up less than $0.4 \%$ of sampled mineral soil dry weight, which may have favored the screening of free-living fungal species over mycorrhizal fungi. Overstory needle fall was the primary source of abundant litter at our sites, however, it was not linked to observed site-level trends. Availability of labile organic matter favors mineralization over sequestration (Manzoni et al., 2008; Prescott, 2010) as dissolved organic matter infiltrates into mineral soils. The increase in $A m o A$ bacteria diversity and richness in mineral soils with increased fern cover (Supplementary Table S8) concurs with the previously established relationship between sword fern and more nutrient rich sites (Green and Klinka, 1994) and suggests patchy layout of $\mathrm{N}$-sources and sinks at most sites (Ramette and Tiedje, 2007a). The observed correlations between moss cover and the composition of $\mathrm{NifH}$ bacterial communities in forest floors (Supplementary Table S7) supports other studies showing high diversity and abundance of $\mathrm{N}$-fixing bacteria in moss-dominated ecosystems (Opelt et al., 2007; Winder and Trofymow, unpublished data) and are indicative of nutrient poor sites, likely favoring nitrogen fixation. The lack of significant relationships between fern or moss cover with soil-N or $\mathrm{C} / \mathrm{N}$ could be due to differences between $\mathrm{N}$-concentrations and $\mathrm{N}$-availability for plants (Schimel and Bennett, 2004); the latter which was not measured. Symbiosis with ericoid mycorrhizae may be responsible for the small but significant association of salal with the composition of AmoA and NifH in the forest floor and mineral soils, respectively (Marschner and Dell, 1994).

\section{Microbial Communities in Forest Floor}

The composition (i.e., assemblage of OTUs) of microbial communities responsible for decay and $\mathrm{N}$-cycling changed markedly along a latitudinal gradient, but without shifts in community structure (i.e., diversity, richness and evenness indices). At the spatial scales involved, it is possible that climatic conditions in forest floors select for different species while maintaining overall ecosystem functions. Fungal community structure was primarily influenced by edaphic characteristics, which constituted most local heterogeneity. In contrast, fungal community composition was primarily influenced by climatic factors, which changed over larger spatial scales. At least for fungi in the forest floor, climate selected for local population pools, while heterogenous soil matrices determine colonization success for particular microbial species at the site level; confirming findings of Ramette and Tiedje (2007a) concerning the influence of environmental heterogeneity at multiple spatial scales. Spatial distance, whether the result of dispersal limitations or geographic isolation, is an influential factor distinguishing microbial communities (Green et al., 2004; Ramette and Tiedje, 2007b; Monroy et al., 2012) and has likely partially confounded the estimation of other site effects, especially along our latitudinal range. However, our experimental design should mitigate this issue, making distance effects likely attributable to some of the difference in \% inertia explained by latitude/zone models and those using climate, edaphic characteristics and vegetation cover ( $\sim 5 \%$ of forest floor microbial composition).

Overall microbial composition was correlated with soil moisture ( $\mathrm{MS}$ and $\mathrm{MS}_{\min }$ ), however, the effects of MS were negated by $\mathrm{pH}$ differences. Isolating the direct effects of MS on microbial communities may be difficult since climatic variables such as precipitation, which control soil moisture, also increase the dissociation of acidic fractions from organic litter. This disassociation in turn lowers pH (Brady and Weil, 2008), as seen with the negative correlation of MS and $\mathrm{pH}(r=-0.4239$, $P=0.01$ ). The observed association of $\mathrm{MS}_{\min }$ (ranging from 0 to $2.47 \%$ ) with microbial composition is supported by evidence of varying desiccation tolerances among microbial taxa (Vangestel et al., 1993).

Degree days was an important predictor of overall microbial composition, potentially due to concurrent effects on forest productivity, in agreement with studies of warming-induced feedbacks between above- and below-ground processes (Melillo et al., 2002). Temperature variables were also associated with 
local $A m o A$ bacteria community structure, emphasizing the role of local climate in selecting microbial community assemblages. Climate should therefore be considered as a potential force for aboveground co-adaptation with forest floor microbial communities.

Fungal community structure was affected primarily by $\mathrm{N}$ and $\mathrm{pH}$. Soil $\mathrm{pH}$ has been shown to be a major predictor of the community structure and composition of bacteria and fungi across biomes (Staddon et al., 1998; Fierer et al., 2009; Strickland and Rousk, 2010; Tedersoo et al., 2014). The observed influence of $\mathrm{N}$ on fungal community structure is in accordance with ectomycorrhizal species showing shifts in species dominance along N-gradients (Lilleskov et al., 2001; Toljander et al., 2006; Kranabetter et al., 2009). As more $\mathrm{N}$ becomes accessible, a few dominant fungal species tolerant to nutrient stress or specializing in the decay of recalcitrant compounds are likely outcompeted by a richer group of generalists.

\section{Microbial Communities in Mineral Soil}

Soil moisture (MS) was an important predictor of both microbial community structure and composition in mineral soils, especially for $\mathrm{N}$-fixing and ammonia-oxidizing bacteria; however, $\mathrm{pH}$ again confounded interpretation of the climatic effect on community structure. Many of the significant differences in community structure were found in the DF zone, where MS negatively correlated with $\mathrm{pH}(r=-0.61 ; P=0.034)$. Both factors are likely the result of water regime and its role in cation precipitation and podzolisation (Brady and Weil, 2008). Our 'mid-scale' study across two nearby biogeoclimatic zones supports other large-scale studies identifying edaphic characteristics, mainly $\mathrm{pH}$, as the primary control of microbial richness and diversity between ecosystem types (Fierer and Jackson, 2006; Fierer et al., 2009; Lauber et al., 2009; Tedersoo et al., 2014) and findings that soil $\mathrm{pH}$ generally affect bacteria more than fungi (Rousk et al., 2010). Although $\mathrm{pH}$ differed significantly between $\mathrm{WH}$ and DF zones (Supplementary Table S3), its effects were not uniform across functional groups, zone, or soil layer, the latter in contrast with the effects outlined above. Soil $\mathrm{pH}$ accounted for fewer changes in microbial composition than local climate, as seen at a global scale in fungal communities (Tedersoo et al., 2014).

Temperature and moisture effects on microbial communities are most likely species- and system-specific (Strickland and Rousk, 2010). Our best climatic descriptors for microbial composition changed from one functional group to the next, but in general did not select for different community structure (Supplementary Table S8). If the community structure of targeted functional groups relates to biological activity, then it is possible that distinct assemblages of microbial populations parallel similar ecosystem functions along climatic gradients within the same forest type. Such selection potentially results from narrower niche widths for some microbes than their host (Nantel and Neumann, 1992; Kranabetter, 2014). Localized co-adaptation of endemic plant populations and microbiota is also a possibility (Kranabetter, 2014), since genotype can have major influences on underground microbiota (Schweitzer et al., 2008). While some of the tree stands at our sites were planted, selected genotypes would have been of locally adapted stock.

Warmer climates tend to have accelerated rates of decay and mineralization (Melillo et al., 2002), which could account for the increased diversity and richness of $A m o A$ bacteria with increasing DD at some sites (Supplementary Table S8b). The composition of NifH communities was also influenced by DD without effects on general structure (Supplementary Table $\mathrm{S} 8 \mathrm{~b}$ ), further emphasizing the role of temperature in selecting microbial populations along climatic gradients. This process could potentially lead to population endemism. Cosmopolitan gene transfer could also allow for distinct, locally adapted populations to share a common function in response to ecological pressures at a larger scale (Ramette and Tiedje, 2007b). Temperature extremes at the local scale were also shown to play an important role in the selection of microbial populations, namely fungi and $\mathrm{NifH}$ bacteria (Supplemental Table S8b).

Although we did not measure $\mathrm{N}$-dynamics, mineral soil $\mathrm{C} / \mathrm{N}$ could be reflective of the $\mathrm{N}$-availability to microbes, since microbial communities shifted from fungi to nitrogenfixing bacteria with decreasing quality of soil organic matter (Figure 4B). Shifts in dominant functional groups and changes in the composition of fungal communities demonstrate significant alterations of microbial niches along $\mathrm{N}$-gradients, further emphasizing the importance of this element for determining trophic cascades (e.g., Knops et al., 2002; Schimel and Bennett, 2004; Kranabetter et al., 2009). Total $\mathrm{C}$ has been shown to affect the abundance of forest floor NifH bacteria in DF stands with different thinning densities (Levy-Booth and Winder, 2010). We further showed that $\mathrm{C}$ significantly correlated with the community structure of forest floor NifH bacteria and mineral soil $\mathrm{NifH}$ bacteria in DF stands along temperature and moisture gradients.

The increases in fungal community structure indices associated with increased fine fraction content in mineral soil may be a result of greater sample size. Although DNA was extracted from subsamples of the same mass, these were taken from homogenized fine fraction content of different sizes (by weight), which may affect the probability of sampling species. Effects of fine fraction content on the community composition of NifH bacteria were less clear. Since sample volumes and depth were maintained as constants, fine fraction content was linked to density and therefore could also be related to soil aeration and drainage; however, gravel content and soil compaction complicate this relationship.

\section{Spatial Implications for Microbial Biogeography}

Spatial scales segregating latitude and biogeoclimatic zones are important in determining community structure and composition of nutrient cycling microbes along the rainshadow forests of East Vancouver Island. The spatial component associated with latitude was of particular importance in accounting for microbial variability, in part since spatial distance between s-, c-, and n-transects was greater than distances between zones or plots at each latitude, supporting earlier findings that increasing spatial 
distance decreases microbial community similarity (Martiny et al., 2006). These effects were particularly pronounced for community structure in mineral soil. Since latitude and zone lose their explanatory power when the effects of environmental variables are removed, PCNM components 3, 4, and 5 likely delineate spatial boundaries correlated to environmental factors significantly affecting microbial communities. Even though these spatial boundaries (i.e., shared spatio-environmental effects) only account for a small fraction of total community variances, they compose a substantial fraction of the explicable community structure (Table 3). The generally greater explanatory power of environmental variables therefore does not preclude the importance of spatial and shared spatio-environmental effects on microbial biogeography, especially on species with dispersal limitations (e.g., Tedersoo et al., 2014). The joint influence of climate and spatial distance on nutrient-cycling microbes, even within the same ecosystem type (Table 3; Green et al., 2004; Monroy et al., 2012), could infer that 'naïve' tree genotypes experiencing climatic shifts or undergoing assisted migration (Winder et al., 2011) have greater exposure to novel soil biota and more potential disconnection from co-adapted communities.

\section{Conclusion}

Climatic and soil factors held the most explanatory power regarding variability of microbial communities in Douglas-fir forest soils. Significant changes in the microbial community composition and structure were related to differences as small as $2.47 \%$ and $2.55^{\circ} \mathrm{C}$ in mean annual moisture and temperature parameters, respectively. The climatic variables best describing microbial composition changed from one functional group to the next, and in general could not be attributed

\section{References}

Bahram, M., Polme, S., Koljalg, U., Zarre, S., and Tedersoo, L. (2012). Regional and local patterns of ectomycorrhizal fungal diversity and community structure along an altitudinal gradient in the Hyrcanian forests of northern Iran. New Phytol. 193, 465-473. doi: 10.1111/j.1469-8137.2011. 03927.x

Borcard, D., Legendre, P., Avois-Jacquet, C., and Tuomisto, H. (2004). Dissecting the spatial structure of ecological data at multiple scales. Ecology 85, 1826-1832. doi: 10.1890/03-3111

Borcard, D., Legendre, P., and Drapeau, P. (1992). Partialling out the spatial component of ecological variation. Ecology 73, 1045-1055. doi: $10.2307 / 1940179$

Brady, N. C., and Weil, R. R. (2008). "Soil organic matter," in The Nature and Properties of Soils, 14th Edn, ed. V. R. Anthony (Upper Saddle River, NJ: Pearson Education Inc.), 495-541.

Burgmann, H., Meier, S., Bunge, M., Widmer, F., and Zeyer, J. (2005). Effects of model root exudates on structure and activity of a soil diazotroph community. Environ. Microbiol. 7, 1711-1724. doi: 10.1111/j.1462-2920.2005. 00818.x

Chowdhury, N., Marschner, P., and Burns, R. G. (2011). Soil microbial activity and community composition: impact of changes in matric and osmotic potential. Soil Biol. Biochem. 43, 1229-1236. doi: 10.1016/j.soilbio.2011.02.012

Ecoregions Working Group (1989). Ecoclimatic Regions of Canada, First Approximation. Ottawa: Environment Canada. to changes in community structure due to correlations with other environmental characteristics. To a lesser extent, spatial distance, especially associated with latitude, was also important in accounting for community variability. The influence of climate regimes on niche distribution may vary between species and life forms. Special consideration for the interaction of complex above- and below-ground communities is suggested for the development of forest management methods pertaining to climate change adaptation, and warrants further research.

\section{Author Contributions}

PS, RW, and JT conceived and designed the study. PS collected and analyzed the data. PS, RW and JT wrote the manuscript.

\section{Acknowledgments}

We would like to thank Dr. Sari Saunders and Heather Klassen (B.C. Ministry of Forest) for site-level climate and vegetation data and David Dunn and Grace Ross (PFC) for help with chemical analyses. The work was funded by the NSERC CREATE Program in Forests and Climate Change, in a collaborative agreement between the University of Victoria and Natural Resources Canada. It was also supported by the CFS Climate Change Adaptation Project.

\section{Supplementary Material}

The Supplementary Material for this article can be found online at: http://journal.frontiersin.org/article/10.3389/fmicb. 2015.01097

Elsas, J. D. V., Torsvik, V., Hartmann, A., Ovreas, L., and Jansson, J. K. (2007). “The bacteria and archaea in soil," in Modern Soil Microbiology, eds J. D. V. Elsas, J. K. Jansson, and J. T. Trevors (Boca Raton, FL: CRC Press), 83-106.

Fierer, N., and Jackson, R. B. (2006). The diversity and biogeography of soil bacterial communities. Proc. Natl. Acad. Sci. U.S.A. 103, 626-631. doi: 10.1073/pnas.0507535103

Fierer, N., Strickland, M. S., Liptzin, D., Bradford, M. A., and Cleveland, C. C. (2009). Global patterns in belowground communities. Ecol. Lett. 12, 1238-1249. doi: 10.1111/j.1461-0248.2009. 01360.x

Finlay, R. D. (2007). “The fungi in soil," in Modern Soil Microbiology, eds J. D. V. Elsas, J. K. Jansson, and J. T. Trevors (Boca Raton, FL: CRC Press), 107-146.

Finlay, R. D., Frostegard, A., and Sonnerfeldt, A. M. (1992). Utilization of organic and inorganic nitrogen-sources by ectomycorrhizal fungi in pure culture and in symbiosis with Pinus contorta Dougl. ex loud. New Phytol. 120, 105-115. doi: 10.1111/j.1469-8137.1992.tb01063.x

Finzi, A. C., Van Breemen, N., and Canham, C. D. (1998). Canopy tree soil interactions within temperate forests: species effects on soil carbon and nitrogen. Ecol. Appl. 8, 440-446. doi: 10.2307/2641083

Fromin, N., Hamelin, J., Tarnawski, S., Roesti, D., Jourdain-Miserez, K., Forestier, N., et al. (2002). Statistical analysis of denaturing gel electrophoresis (DGE) fingerprinting patterns. Environ. Microbiol. 4, 634-643. doi: 10.1046/j.1462-2920.2002.00358.x

Gijsman, A. J. (1991). Soil-water content as a key factor determining the source of nitrogen (NH4+or NO3-) absorbed by Douglas fir (Pseudotsuga menziesii) and 
the pattern of rhizosphere $\mathrm{pH}$ along its roots. Can. J. For. Res. 21, 616-625. doi: 10.1139/x91-085

Glick, B. R., Patten, C. L., Holguin, G., and Penrose, D. M. (1999). Biochemical and Genetic Mechanisms Used by Plant Growth-Promoting Bacteria. London: Imperial College Press.

Godinez-Dominguez, E., and Freire, J. (2003). Information-theoretic approach for selection of spatial and temporal models of community organization. Mar. Ecol. Prog. Ser. 253, 17-24. doi: 10.3354/meps 253017

Green, J. L., Holmes, A. J., Westoby, M., Oliver, I., Briscoe, D., Dangerfield, M., et al. (2004). Spatial scaling of microbial eukaryote diversity. Nature 432, 747-750. doi: 10.1038/nature03034

Green, R. N., and Klinka, K. (1994). "A field guide for site identification and interpretation in the Vancouver Forest Region," in Land Management Handbook 28 (Victoria, BC: Research Branch, British Columbia Ministry of Forests).

Hamann, A., and Wang, T. L. (2006). Potential effects of climate change on ecosystem and tree species distribution in British Columbia. Ecology 87, 27732786.

Hoshino, Y. T., and Morimoto, S. (2010). Soil clone library analyses to evaluate specificity and selectivity of pcr primers targeting fungal $18 \mathrm{~s}$ rdna for denaturing-gradient gel electrophoresis (DGGE). Microbes Environ. 25, 281287. doi: 10.1264/jsme2.ME10136

Josse, J., Pages, J., and Husson, F. (2011). Multiple imputation in principal component analysis. Advan. Data Anal. Classif. 5, 231-246. doi: 10.1007/s11634-011-0086-7

Junier, P., Kim, O. S., Junier, T., Ahn, T. S., Imhoff, J. F., and Witzel, K. P. (2009). Community analysis of betaproteobacterial ammonia-oxidizing bacteria using the amoCAB operon. Appl. Microbiol. Biotechnol. 83, 175-188. doi: 10.1007/s00253-009-1923-x

Kalra, Y. P., and Maynard, D. G. (1991). Methods Manual for Forest Soil and Plant Analysis. Edmonton, AB: Northwest Registered.

Kankainen, A., Taskinen, S., and Oja, H. (2007). Tests of multinormality based on location vectors and scatter matrices. Stat. Methods Appl. 16, 357-379. doi: 10.1007/s10260-007-0045-9

Klotz, M. G., and Norton, J. M. (1995). Sequence of an ammonia monooxygenase subunit a-encoding gene from Nitrosospira sp NPAV. Gene 163, 159-160. doi: 10.1016/0378-1119(95)00392-j

Knops, J. M. H., Bradley, K. L., and Wedin, D. A. (2002). Mechanisms of plant species impacts on ecosystem nitrogen cycling. Ecol. Lett. 5, 454-466. doi: 10.1046/j.1461-0248.2002.00332.x

Kowalchuk, G. A., Stephen, J. R., Deboer, W., Prosser, J. I., Embley, T. M., and Woldendorp, J. W. (1997). Analysis of ammonia-oxidizing bacteria of the beta subdivision of the class Proteobacteria in coastal sand dunes by denaturing gradient gel electrophoresis and sequencing of PCRamplified 16S ribosomal DNA fragments. Appl. Environ. Microbiol. 63, 1489-1497.

Kranabetter, J. M. (2014). Ectomycorrhizal fungi and the nitrogen economy of conifers - implications for genecology and climate change mitigation. Botany 92, 417-423. doi: 10.1139/cjb-2013-0198

Kranabetter, J. M., Durall, D. M., and Mackenzie, W. H. (2009). Diversity and species distribution of ectomycorrhizal fungi along productivity gradients of a southern boreal forest. Mycorrhiza 19, 99-111. doi: 10.1007/s00572008-0208-z

Lauber, C. L., Hamady, M., Knight, R., and Fierer, N. (2009). Pyrosequencingbased assessment of soil ph as a predictor of soil bacterial community structure at the continental scale. Appl. Environ. Microbiol. 75, 5111-5120. doi: 10.1128/aem.00335-09

Legendre, P., and Birks, H. J. B. (2012). "From classical to canonical ordination," in Tracking Environmental Change using Lake Sediments,: Data handling and numerical techniques, Vol. 5, eds H. J. B. Birks, A. F. Lotter, S. Juggins, and J. P. Smol (Dordrecht: Springer), 201-248.

Legendre, P., Borcard, D., and Peres-Neto, P. R. (2005). Analyzing beta diversity: partitioning the spatial variation of community composition data. Ecol. Monogr. 75, 435-450. doi: 10.1890/05-0549

Levy-Booth, D. J., and Winder, R. S. (2010). Quantification of nitrogen reductase and nitrite reductase genes in soil of thinned and clear-cut douglas-fir stands by using real-time PCR. Appl. Environ. Microbiol. 76, 7116-7125. doi: 10.1128/aem.02188-09
Lilleskov, E. A., Fahey, T. J., and Lovett, G. M. (2001). Ectomycorrhizal fungal aboveground community change over an atmospheric nitrogen deposition gradient. Ecol. Appl. 11, 397-410. doi: 10.2307/3060897

Manzoni, S., Jackson, R. B., Trofymow, J. A., and Porporato, A. (2008). The global stoichiometry of litter nitrogen mineralization. Science 321, 684-686. doi: 10.1126/science. 1159792

Marschner, H., and Dell, B. (1994). Nutrient-uptake in mycorrhizal symbiosis. Plant Soil 159, 89-102.

Martiny, J. B. H., Bohannan, B. J. M., Brown, J. H., Colwell, R. K., Fuhrman, J. A., Green, J. L., et al. (2006). Microbial biogeography: putting microorganisms on the map. Nat. Rev. Microbiol. 4, 102-112. doi: 10.1038/nrmicro1341

McTavish, H., Fuchs, J. A., and Hooper, A. B. (1993). Sequence of the gene coding for ammonia monooxygenase in Nitrosomonas europaea. J. Bacteriol. $175,2436-2444$.

Meidinger, D. V., and Pojar, J. (1991). "Ecosystems of British Columbia," in Special Report Series, eds D. V. Meidinger and J. Pojar (Victoria, BC: BC Ministry of Forests).

Melillo, J. M., Steudler, P. A., Aber, J. D., Newkirk, K., Lux, H., Bowles, F. P., et al. (2002). Soil warming and carbon-cycle feedbacks to the climate system. Science 298, 2173-2176. doi: 10.1126/science.1074153

Monroy, F., Van Der Putten, W. H., Yergeau, E., Mortimer, S. R., Duyts, H., and Bezemer, T. M. (2012). Community patterns of soil bacteria and nematodes in relation to geographic distance. Soil Biol. Biochem. 45, 1-7. doi: 10.1016/j.soilbio.2011.10.006

Morrien, E., Engelkes, T., and Van Der Putten, W. H. (2011). Additive effects of aboveground polyphagous herbivores and soil feedback in native and rangeexpanding exotic plants. Ecology 92, 1344-1352. doi: 10.1890/10-1937.1

Muyzer, G., de waal, E. C., and Uitterlinden, A. G. (1993). Profiling of complex microbial populations by denaturing gradient gel electrophoresis analysis of polymerase chain reaction-amplified genes coding for $16 \mathrm{~S}$ rRNA. Appl. Environ. Microbiol. 59, 695-700.

Muyzer, G., and Smalla, K. (1998). Application of denaturing gradient gel electrophoresis (DGGE) and temperature gradient gel electrophoresis (TGGE) in microbial ecology. Antonie Van Leeuwenhoek 73, 127-141. doi: 10.1023/a:1000669317571

Nantel, P., and Neumann, P. (1992). Ecology of ectomycorrhizal-basidiomycete communities on a local vegetation gradient. Ecology 73, 99-117. doi: $10.2307 / 1938724$

Nicolaisen, M. H., and Ramsing, N. B. (2002). Denaturing gradient gel electrophoresis (DGGE) approaches to study the diversity of ammoniaoxidizing bacteria. J. Microbiol. Methods 50, 189-203. doi: 10.1016/s01677012(02)00026-x

Norton, J. M., Alzerreca, J. J., Suwa, Y., and Klotz, M. G. (2002). Diversity of ammonia monooxygenase operon in autotrophic ammonia-oxidizing bacteria. Arch. Microbiol. 177, 139-149. doi: 10.1007/s00203-0010369-z

Oksanen, J., Blanchet, F. G., Kindt, R., Legendre, P., Minchin, P. R., O'Hara, R. B., et al. (2015). Vegan: Community Ecology Package. R Package Version 2.2-1. Available at: http://CRAN.R-project.org/package=vegan

Opelt, K., Chobot, V., Hadacek, F., Schonmann, S., Eberl, L., and Berg, G. (2007). Investigations of the structure and function of bacterial communities associated with Sphagnum mosses. Environ. Microbiol. 9, 2795-2809. doi: 10.1111/j.14622920.2007.01391.x

Oros-Sichler, M., Costa, R., Heuer, H., and Smalla, K. (2007). "Molecular fingerprinting techniques to analyse soil microbial comunities," in Modern Soil Microbiology, 2nd Edn, eds J. D. Van Elsas, J. K. Jansson, and J. T. Trevors (Boca Raton, FL: CRC Press), 355-386.

Prescott, C. E. (2010). Litter decomposition: what controls it and how can we alter it to sequester more carbon in forest soils? Biogeochemistry 101, 133-149. doi: 10.1007/s10533-010-9439-0

Prescott, C. E., Mcdonald, M. A., and Weetman, G. F. (1993). Availability of N and $\mathrm{P}$ in the forest floors of adjacent stands of western red cedar - western hemlock and western hemlock - amabilis fir on Northern Vancouver-Island. Can. J. For. Res. 23, 605-610. doi: 10.1139/x93-080

Prosser, J. I. (2007). "Microorganisms cycling soil nutrients and their diversity," in Modern Soil Microbiology, eds J. D. V. Elsas, J. K. Jansson, and J. T. Trevors (Boca Raton, FL: CRC Press), 237-261. 
Ramette, A., and Tiedje, J. M. (2007a). Biogeography: an emerging cornerstone for understanding prokaryotic diversity, ecology, and evolution. Microb. Ecol. 53, 197-207. doi: 10.1007/s00248-005-5010-2

Ramette, A., and Tiedje, J. M. (2007b). Multiscale responses of microbial life to spatial distance and environmental heterogeneity in a patchy ecosystem. Proc. Natl. Acad. Sci. U.S.A. 104, 2761-2766. doi: 10.1073/pnas.0610671104

R Development Core Team (2014). R: A Language and Environment for Statistical Computing. Vienna: R Foundation for Statistical Computing.

Rotthauwe, J. H., Witzel, K. P., and Liesack, W. (1997). The ammonia monooxygenase structural gene amoA as a functional marker: molecular fine-scale analysis of natural ammonia-oxidizing populations. Appl. Environ. Microbiol. 63, 4704-4712.

Rousk, J., Baath, E., Brookes, P. C., Lauber, C. L., Lozupone, C., Caporaso, J. G., et al. (2010). Soil bacterial and fungal communities across a $\mathrm{pH}$ gradient in an arable soil. ISME J. 4, 1340-1351. doi: 10.1038/ismej.2010.58

Schimel, J. P., and Bennett, J. (2004). Nitrogen mineralization: challenges of a changing paradigm. Ecology 85, 591-602. doi: 10.1890/03-8002

Schweitzer, J. A., Bailey, J. K., Fischer, D. G., Leroy, C. J., Lonsdorf, E. V., Whitham, T. G., et al. (2008). Plant-soil-microorganism interactions: heritable relationship between plant genotype and associated soil microorganisms. Ecology 89, 773781. doi: 10.1890/07-0337.1

Sheffield, V. C., Cox, D. R., Lerman, L. S., and Myers, R. M. (1987). Attachment of a 40-base pair $\mathrm{G}+\mathrm{C}$-rich sequence (GC-clamp) to genomic DNA fragments by the polymerase chain reaction results in improved detection of singlebase changes. Proc. Natl. Acad. Sci. U.S.A. 86, 232-236. doi: 10.1073/pnas.86. 1.232

Staddon, W. J., Trevors, J. T., Duchesne, L. C., and Colombo, C. A. (1998). Soil microbial diversity and community structure across a climatic gradient in western Canada. Biodiver. Conserv. 7, 1081-1092. doi: 10.1023/a:1008813232395

Ste-Marie, C., and Houle, D. (2006). Forest floor gross and net nitrogen mineralization in three forest types in Quebec. Canada. Soil Biol. Biochem. 38, 2135-2143. doi: 10.1016/j.soilbio.2006. 01.017

Strickland, M. S., and Rousk, J. (2010). Considering fungal:bacterial dominance in soils - Methods, controls, and ecosystem implications. Soil Biol. Biochem. 42, 1385-1395. doi: 10.1016/j.soilbio.2010.05.007

Tedersoo, L., Bahram, M., Polme, S., Koljalg, U., Yorou, N. S., Wijesundera, R., et al. (2014). Global diversity and geography of soil fungi. Science 346, 1078 . doi: 10.1126/science. 1256688

Tedersoo, L., Bahram, M., Toots, M., Diedhiou, A. G., Henkel, T. W., Kjoller, R., et al. (2012). Towards global patterns in the diversity and community structure of ectomycorrhizal fungi. Mol. Ecol. 21, 4160-4170. doi: 10.1111/j.1365294X.2012.05602.x
Toljander, J. F., Eberhardt, U., Toljander, Y. K., Paul, L. R., and Taylor, A. F. S. (2006). Species composition of an ectomycorrhizal fungal community along a local nutrient gradient in a boreal forest. New Phytol. 170, 873-883. doi: 10.1111/j.1469-8137.2006.01718.x

Turner, D. P., Sollins, P., Leuking, M., and Rudd, N. (1993). Availability and uptake of inorganic nitrogen in a mixed old-growth coniferous forest. Plant Soil 148, 163-174. doi: 10.1007/bf00012854

Vainio, E. J., Hallaksela, A. M., Lipponen, K., and Hantula, J. (2005). Direct analysis of ribosomal DNA in denaturing gradients: application on the effects of Phlebiopsis gigantea treatment on fungal communities of conifer stumps. Mycol. Res. 109, 103-114. doi: 10.1017/s0953756204001406

Vainio, E. J., and Hantula, J. (2000). Direct analysis of wood-inhabiting fungi using denaturing gradient gel electrophoresis of amplified ribosomal DNA. Mycol. Res. 104, 927-936. doi: 10.1017/s0953756200002471

van der Heijden, M. G. A., Bardgett, R. D., and Van Straalen, N. M. (2008). The unseen majority: soil microbes as drivers of plant diversity and productivity in terrestrial ecosystems. Ecol. Lett. 11, 296-310. doi: 10.1111/j.1461-0248.2007.01139.x

Vangestel, M., Merckx, R., and Vlassak, K. (1993). Microbial biomass responses to soil drying and rewetting - the fate of fast-growing and slow-growing microorganisms in soils from different climates. Soil Biol. Biochem. 25, 109-123. doi: 10.1016/0038-0717(93)90249-b

Vitousek, P. M., and Howarth, R. W. (1991). Nitrogen limitation on land and in the sea - how can it occur. Biogeochemistry 13, 87-115. doi: 10.1007/BF00002772

Wardle, D. A., Bardgett, R. D., Klironomos, J. N., Setala, H., Van Der Putten, W. H., and Wall, D. H. (2004). Ecological linkages between aboveground and belowground biota. Science 304, 1629-1633. doi: 10.1126/science.1094875

Widmer, F., Shaffer, B. T., Porteous, L. A., and Seidler, R. J. (1999). Analysis of nifH gene pool complexity in soil and litter at a Douglas fir forest site in the Oregon Cascade Mountain Range. Appl. Environ. Microbiol. 65, 374-380.

Winder, R., Nelson, E. A., and Beardmore, T. (2011). Ecological implications for assisted migration in Canadian forests. For. Chronicle 87, 731-744. doi: $10.5558 / \mathrm{tfc} 2011-090$

Conflict of Interest Statement: The authors declare that the research was conducted in the absence of any commercial or financial relationships that could be construed as a potential conflict of interest.

Copyright (c) 2015 Shay, Winder and Trofymow. This is an open-access article distributed under the terms of the Creative Commons Attribution License (CC BY). The use, distribution or reproduction in other forums is permitted, provided the original author(s) or licensor are credited and that the original publication in this journal is cited, in accordance with accepted academic practice. No use, distribution or reproduction is permitted which does not comply with these terms. 